\section{Who Is Paying for Higher Education-and Why?}

\section{Philip G. Altbach}

Philip G. Altbach is J. Donald Monan, S. J. professor of higher education and director of the Center for International Higher Education at Boston College.

\begin{abstract}
A key debate in the United States, as in other countries, relates to the cost of higher education, whether higher education is affordable, especially for students from lower-income families, and where the responsibility for funding postsecondary education should lie. Recently, the Lumina Foundation, a private research group, released a study claiming that the cost of college is skyrocketing. It is said that low-income students can no longer afford to attend college, that a growing number of graduates are saddled with massive debts after graduation, and that higher costs have led to a growing dropout problem and diminishing access. The implication is that colleges and universities are gouging students and their families. The reality is more complex than the headlines indicate, and it is not true that public colleges are overcharging. Lumina has highlighted a key reality of higher education in the new millennium-in America and much of the rest of the world, the cost of higher education has been shifted from the state to the student. It is not a surprise that costs have shot up. Indeed, it is part of a long-term and deliberate policy initiative by government at all levels.

There are three elements to this tectonic shift in public higher education policy over the past three decades. They can be summarized as public good vs. private good, high tuition and high aid, and send the masses to the community colleges.
\end{abstract}

\section{Public and Private Benefits}

Public higher education was at one time based on the belief that college and university degrees benefited society by adding to the skills of the population, and thereby improving the economy, increasing tax revenues, and in general adding to the "public good." The more people who could attend college and benefit from advanced study, the better. The data are very clear that a college degree leads to higher income and greater civic participation. It is, without question, a good investment. Because of the clear social benefits of higher education, society, it was argued, should invest in it. There was general agreement in most states and at the federal level that government should provide most of the funding for public higher education. That commitment started to erode in the 1970s, when conservative economists began to argue that the benefits accruing with higher education went to individuals, and were therefore a "private good" for which individuals and their families should pay. An additional concomitant of the private good idea is that grants have been changed to loans-placing major burdens on many college graduates. This ideological shift, combined with growing pressures on public budgets, led to a dramatic change in thinking about public higher education. Most states have been slowly shifting the cost of public higher education from tax revenues to tuition paid by students. Many states now provide less than one-third the cost of public higher education, with students paying the rest.

\section{High Tuition-High Aid}

Another major public policy change in many states has been an effort to ensure that those who can afford to pay for public higher education are charged and those who need financial assistance receive it. In the old days, studies found that many students attending public universities were from families who could have afforded to pay a reasonably high tuition. The state was basically subsidizing the wealthy. Faced with fiscal shortfalls, tuition levels were raised and money put aside for needs-based scholarships and grant programs. The concept of high tuition-high aid makes sense in an era of limited public spending as it ensures access to those who cannot afford tuition. The problem is that in many states high tuition has remained but "high aid" has not been maintainedthe result being that the poor are in some ways even worse off.

The implication is that colleges and universities are gouging students and their families.

\section{The Community Colleges}

Increasing numbers of students have been encouraged to attend two-year community colleges for the first part of undergraduate education, transferring to a four-year school for the completion of their studies. Community colleges typically charge lower tuition-and they are much less costly for the states to operate than are fouryear colleges. Thus, students save money through lower direct tuition and the states save by the lower operating costs. Students may also save on housing costs because they usually attend community colleges within commuting distance. Students, however, lose the experience of the campus environment and the curricular continuity and coherence of a four-year college education. Policymakers love the community college alternative simply because it saves money. 


\section{Other Examples}

Other countries offer alternatives to American thinking. In Western Europe, tuition remains low, or in some cases entirely free. There is still a commitment to the public good argument. The European experience shows that modern postindustrial societies can support public higher education systems and provide access to growing numbers of students. In Australia, where there has been a U.S.-style shift to the private good idea, the funding system is based on a concept of a tax on the earnings of university graduates-degree holders pay back the cost of their higher education, over time, based on their incomes. There is less of an immediate burden on individuals and a greater degree of equity. These examples show that there are other ways to think about financing large higher education systems.

\section{The Logic of the System}

The unaffordability of public higher education that the Lumina Foundation highlights is no surprise. Indeed, it is a logical and inevitable result of the changes in public policy of the recent past. To make higher education more affordable will require another philosophical and ideological change-one that is unlikely to occur in today's political and economic climate.

\section{Perspectives on}

\section{Internationalizing Higher Education \\ Philip G. Altbach}

Philip G. Altbach is J. Donald Monan, S.J. professor of higher education and director of the Center for International Higher Education at Boston College.

Tnternationalization is a major trend in higher educa Ition. It is also a worldwide phenomenon. And it is widely misunderstood. The aim of this article is to identify current themes in internationalization and to point to some of the new sources that will provide useful, albeit provocative, perspectives and analyses. It discusses the books and documents listed at the end.

The elements of globalization in higher education are widespread and multifaceted. They include flows of students across borders: it is estimated that more than 1.6 million students now study outside of their home countries, with more than 547,000 studying in the United States. International branch and off-shore campuses now dot the landscape, especially in developing and middleincome countries. In American colleges and universities, programs aimed at providing an international perspective and cross-cultural skills to American students are increasingly popular. These represent just a few dimensions of this growing trend. At the same time, in the United States at least, there is much more rhetoric than action concerning the internationalization of higher education.

A conceptual understanding of globalization and internationalization is needed to make sense of the varied and complex ways they are affecting higher education in the United States and worldwide. In broad terms, globalization refers to trends in higher education that have cross-national implications. These include mass higher education; a global marketplace for students, faculty, and highly educated personnel; and the global reach of the new Internet-based technologies, among others. Internationalization refers to the specific policies and initiatives of countries and individual academic institutions or systems to deal with global trends. Examples of internationalization include policies relating to recruitment of foreign students, collaboration with academic institutions or systems in other countries, and the establishment of branch campuses abroad.

Deep inequalities undergird many of the current trends in globalization and internationalization in higher education, and they too need to be understood as part of the picture. A few countries dominate global scientific systems, the new technologies are owned primarily by multinational corporations or academic institutions in the major Western industrialized nations, and the domination of English creates advantages for the countries that use English as the medium of instruction and research. All this means that the developing countries find themselves dependent on the major academic superpowers.

Two works provide comparative global perspectives in international education that are insightful, sensitive and thought-provoking: Hans de Wit's Internationalization of Higher Education in the United States of America and Europe (2002) and Peter Scott's edited volume, The Globalization of Higher Education (1998). De Wit, who until recently was vice president for international relations at the University of Amsterdam in the Netherlands, provides a broad historical and contemporary analysis of internationalization trends in the United States and Europe. While he argues that there have always been international elements in higher education, dating back to the medieval roots of the university, internationalization has not been the primary goal of academe. Internationalization, he argues, has had varied motivations over time: Cold War politics stimulated many of the American international initiatives in the post-World War II era-from the rise of area studies to the National Defense Education Act. In Europe, the 